\title{
Effect of total flavonoids of Cuscuta chinensis Lam. (Convolvulaceae) on oxidative stress injury in mouse testis and epididymis, and on serum levels of reproductive hormones in oligoasthenospermia mice model
}

\author{
Hongliang Cui ${ }^{1}$, Panpan Dong ${ }^{2}$, Bin Chen ${ }^{3 *}$ \\ ${ }^{1}$ Department of Andrology, Nantong Hospital of Traditional Chinese Medicine, Nantong 226001, ${ }^{2}$ Nanjing University of Chinese \\ Medicine, Nanjing 210023, Jiangsu Province, ${ }^{3}$ Department of Traditional Chinese Medicine Surgery, The First People's \\ Hospital of Nantong City, Nantong 226001, China
}

*For correspondence: Email: wztvj7@163.com

Sent for review: 15 February 2019

Revised accepted: 28 May 2019

\begin{abstract}
Purpose: To investigate the effect of total flavonoids of Cuscuta chinensis (TFCC) on oxidative stress injury in testis and epididymis, and serum levels of reproductive hormones in an oligoasthenospermia (OAS) mice model.

Methods: Thirty male Wistar mice were randomly assigned to three groups of 10 mice each: control group, OAS group and TFCC group. With the exception of control group, OAS was orally induced in the mice with ornidazole. The TFCC group received TFCC. Reactive oxygen species (ROS), malondialdehyde (MDA) and superoxide dismutase (SOD) were determined. Serum levels of follicle stimulating hormone (FSH), luteinizing hormone $(\mathrm{LH})$ and testosterone were also measured.

Results: The levels of ROS and MDA in the testis and epididymis significantly increased in OAS group, when compared to control mice $(p<0.05)$. However, TFCC administration significantly reduced their levels in these tissues $(p<0.05)$. In contrast, $S O D$ activity significantly decreased in the testis and epididymis of mice in OAS group, relative to control group, but increased significantly after TFCC exposure $(p<0.05)$. Serum FSH and LH were markedly elevated in OAS group, but treatment with TFCC significantly reduced the levels of these hormones $(p<0.05)$.

Conclusion: These results suggest that TFCC effectively improves sperm quality and reduces oxidative damage in testis and epididymis of mice with oligoasthenospermia via a mechanism involving the regulation of serum levels of reproductive hormones. Thus, TFCC may be useful in the treatment of oligoasthenospermia.
\end{abstract}

Keywords: Total flavonoids, Cuscuta chinensis, Oxidative stress injury, Oligoasthenospermia, Testis, Reproductive hormones

This is an Open Access article that uses a fund-ing model which does not charge readers or their institutions for access and distributed under the terms of the Creative Commons Attribution License (http://creativecommons.org/licenses/by/4.0) and the Budapest Open Access Initiative (http://www.budapestopenaccessinitiative.org/read), which permit unrestricted use, distribution, and reproduction in any medium, provided the original work is properly credited.

Tropical Journal of Pharmaceutical Research is indexed by Science Citation Index (SciSearch), Scopus, International Pharmaceutical Abstract, Chemical Abstracts, Embase, Index Copernicus, EBSCO, African Index Medicus, JournalSeek, Journal Citation Reports/Science Edition, Directory of Open Access Journals (DOAJ), African Journal Online, Bioline International, Open-J-Gate and Pharmacy Abstracts

\section{INTRODUCTION}

Infertility is a global health challenge that affects couples' emotions and family stability. Factors such as reproductive system diseases, mental stress, psychological problems, work pressure, and environmental pollution exert varied degrees of impact on sperm quality [1]. Male factors 
account for more than $50 \%$ of all known causes of infertility. Oligoasthenospermia, a common type of male infertility is characterized by sperm density $<20 \times 10^{9} / \mathrm{L}$, motility $<\mathbb{I}^{\circ}$, percentage motility $<50 \%$, and normal sperm morphology < $60 \%$ [2]. The pathological mechanism of oligoasthenospermia has not been fully elucidated. However, it has been speculated that ROS causes sperm membrane damage, inhibits sperm motility and reduces sperm count. In recent years, the involvement of ROS in the pathogenesis of oligoasthenospermia has received huge attention [3].

Cuscuta chinensis is a parasitic plant in the family Convolvulaceae. It is native to China and it is used in Traditional Chinese Medicine (TCM) for warming and tonification of kidney yang. It contains flavonoids, polysaccharides, sterols and other phytochemicals. It has shown great promise in the treatment of poor sperm quality, testicular lesions and degeneration of gonadal function [4]. The aim of this study was to investigate the effect of TFCC on oxidative stress injury in testis and epididymis, and serum levels of reproductive hormones in oligoasthenospermia mice model.

\section{EXPERIMENTAL}

\section{Materials}

Male Wistar mice were obtained from the Laboratory Animal Center of Medical College of Xi'an Jiaotong University. Ornidazole was obtained from Xi'an Wanlong Pharmaceutical Co., Ltd.; TFCC was a product of Xi'an Kailai Bioengineering Co., Ltd., while ELISA kits were purchased from Elabscience Co., Ltd. Olympus BX60 optical microscope was purchased from Olympus Co., Ltd., while LKB-NOVA ultra-thin slicing machine and ELJU-9000 sperm tester were products of Swiss DAKO Co., Ltd. The study received approval from Animal Ethical Committee of The First People's Hospital of Nantong City (approval no. 20180213), and was carried out in line with "Principles of Laboratory Animal Care", NIH, 1985 [5].

\section{Experimental mice}

Thirty male Wistar mice aged 8 - 12 weeks (weighing 200 to $250 \mathrm{~g}$ ) were used for this study. The mice were put in plastic cages, and had free access to standard feed and water. The mice were exposed to $12 \mathrm{~h}$ light/12 $\mathrm{h}$ dark cycles and maintained at $25{ }^{\circ} \mathrm{C}$ and $48-60 \%$ humidity. They were randomly assigned to three groups of 10 mice each: control group, OAS group and TFCC group.
Induction of oligoasthenospermia and treatment regimen

With the exception of control group, oligoasthenospermia was induced in the mice with ornidazole $(800 \mathrm{mg} / \mathrm{kg}$ bwt/day, $4 \mathrm{ml} / \mathrm{time}$, orally for 28 days). The TFCC group received TFCC (100 mg/kg bwt via gastric perfusion) from the $11^{\text {th }}$ day of induction, for 30 days. The control and OAS groups received equivalent amounts of physiological saline in place of TFCC via gastric perfusion.

\section{Tissue collection}

After the last gastric perfusion, the mice were sacrificed and their testes and epididymis were excised. After incubation with $2 \mathrm{~mL}$ of phosphatebuffered saline (PBS) for $10 \mathrm{~min}$, sperm counting pool was dripped to determine the number and activity of sperm. The testis and epididymis were frozen in liquid nitrogen after washing them with physiological saline.

\section{Biochemical analysis}

Tissue homogenates (10\%) were prepared with PBS and subjected to 15-min centrifugation at $4000 \mathrm{rpm}$. The resultant clear portion obtained was taken and used for biochemical analysis. Levels of ROS and MDA, and activities of SOD, GPx, AC and PDE were determined in tissue homogenates using their respective ELISA kits. Serum levels of FSH, LH, and testosterone were also determined using ELISA.

\section{Statistical analysis}

The results are presented as mean \pm SD. Statistical analysis was carried using with SPSS version 19.0. Groups were compared using Student $t$-test and Chi-squared test. Statistical significance was assumed at $p<0.05$.

\section{RESULTS}

\section{Sperm quality}

Ornidazole-induced oligoasthenospermia signifycantly reduced sperm quality in the mice. However, after treatment with TFCC, the quality of sperm was significantly improved, relative to the OAS group ( $p<0.05$; Table 1$)$.

\section{ROS levels and SOD activity in testes and} epididymis of mice

Table 2 shows that the levels of ROS in the testis and epididymis were significantly increased in the OAS group, when compared with control 
group $(p<0.05)$. However, treatment with TFCC significantly reduced ROS levels in these tissues $(p<0.05)$. In contrast, the activity of SOD was significantly reduced in the tissues of mice in $O A S$ mice, relative to control group, but was significantly increased after treatment with TFCC $(p<0.05)$.

Table 1: Sperm quality of the mice $(n=10)$

\begin{tabular}{|c|c|c|c|}
\hline \multirow[b]{2}{*}{ Group } & \multirow{2}{*}{$\begin{array}{c}\text { Sperm } \\
\text { density } \\
\left(10^{6}\right. \\
\mathrm{m} / \mathrm{L})\end{array}$} & \multicolumn{2}{|c|}{ Number of sperm } \\
\hline & & $\begin{array}{l}\text { Class A } \\
\text { sperm } \\
\text { count }\end{array}$ & $\begin{array}{l}\text { Class } A+B \\
\text { sperm count }\end{array}$ \\
\hline Control & $\begin{array}{c}18.95 \pm \\
2.52\end{array}$ & $\begin{array}{c}22.60 \pm \\
3.53\end{array}$ & $34.20 \pm 5.18$ \\
\hline OAS & $\begin{array}{l}8.15 \pm \\
1.04^{\star}\end{array}$ & $\begin{array}{c}10.28 \pm \\
1.85\end{array}$ & $16.55 \pm 2.40^{*}$ \\
\hline TFCC & $\begin{array}{c}13.30 \pm \\
2.27^{* \#}\end{array}$ & $\begin{array}{c}18.85 \pm \\
2.50^{* \#}\end{array}$ & $28.96 \pm 5.32^{*}$ \\
\hline$f$ & 69.56 & 54.06 & 40.48 \\
\hline $\begin{array}{l}\text { P- } \\
\text { value }\end{array}$ & 0.043 & $<0.001$ & $<0.001$ \\
\hline
\end{tabular}

$P<0.05$, relative to control; ${ }^{\#} p<0.05$, relative to $O A S$ mice

Table 2: ROS levels and SOD activity $(n=10)$

\begin{tabular}{|c|c|c|c|c|}
\hline \multirow{2}{*}{ Group } & \multicolumn{2}{|c|}{ ROS (au) } & \multicolumn{2}{|c|}{ SOD (au) } \\
\hline & Testis & Epididymis & Testis & Epididymis \\
\hline Control & $\begin{array}{r}67.25 \\
\pm 9.13\end{array}$ & $\begin{array}{c}35.12 \pm \\
5.60\end{array}$ & $\begin{array}{c}114.52 \\
\pm \\
19.28\end{array}$ & $\begin{array}{c}89.35 \pm \\
10.27\end{array}$ \\
\hline OAS & $\begin{array}{c}152.33 \\
\pm \\
21.50^{*}\end{array}$ & $\begin{array}{c}103.47 \pm \\
16.86^{\star}\end{array}$ & $\begin{array}{c}36.55 \\
\pm 5.59\end{array}$ & $\begin{array}{c}30.29 \pm \\
5.57^{*}\end{array}$ \\
\hline TFCC & $\begin{array}{c}114.56 \\
\pm \\
17.68^{* \#}\end{array}$ & $\begin{array}{c}81.45 \pm \\
9.32^{* \#}\end{array}$ & $\begin{array}{c}79.66 \\
\pm \\
10.25^{*} \#\end{array}$ & $\begin{array}{c}65.47 \pm \\
8.62^{* \#}\end{array}$ \\
\hline$F$ & 63.53 & 90.73 & 90.08 & 25.61 \\
\hline $\begin{array}{l}P \text { - } \\
\text { value }\end{array}$ & $\begin{array}{c}< \\
0.001\end{array}$ & 0.008 & 0.003 & $<0.001$ \\
\hline
\end{tabular}

$P<0.05$, relative to control; ${ }^{\#} p<0$, relative to $O A S$ mice

\section{MDA levels and GPx activity in mouse testes and epididymis}

The levels of MDA in the testis and epididymis were significantly increased in the OAS group, when compared with control $(p<0.05)$. However, treatment with TFCC significantly reduced MDA levels in these tissues $(p<0.05)$. The activity of GPx was significantly reduced in reproductive tissues of mice in OAS group, relative to control, but was increased after treatment with TFCC ( $p$ $<0.05$; Table 3).

\section{AC and PDE activities in mouse testis and epididymis}

As shown in Table 4, ornidazole-induced oligoasthenospermia significantly reduced the activity of $A C$ in mice. However, after treatment with TFCC, AC activity was significantly increased, relative to the OAS group $(p<0.05)$. In reproductive tissues of mice in OAS group, PDE activity was markedly elevated, relative to control group, but was significantly reduced after treatment with TFCC $(p<0.05)$.

Table 3: MDA levels and activities of GPx activity ( $\mathrm{n}=$ 10)

\begin{tabular}{lcccc}
\hline \multirow{2}{*}{ Group } & \multicolumn{3}{c}{ GPx (au) } & MDA (au) \\
\cline { 2 - 5 } & Testis & Epididymis & Testis & Epididymis \\
\hline \multirow{2}{*}{ Control } & $38.63 \pm$ & $30.25 \pm$ & $6.55 \pm$ & $4.43 \pm 0.66$ \\
& 6.72 & 4.86 & 0.84 & \\
OAS & $13.47 \pm$ & $11.75 \pm$ & 25.26 & $19.36 \pm$ \\
& $1.66^{\star *}$ & $2.20^{*}$ & $\pm .33^{*}$ & $3.28^{*}$ \\
TFCC & $28.16^{* \pm}$ & $23.50^{*} \pm$ & 18.15 & \\
& $4.28^{* \#}$ & $4.26^{* \#}$ & $\pm .76^{* \#}$ & $1.07^{* \#}$ \\
$f$ & 72.35 & 56.42 & 72.85 & 21.98 \\
$P$ - & 0.001 & $<0.001$ & $<$ & $<0.001$ \\
value & 0.001 & $<01$ \\
\hline$p<0.05$, relative to control; ${ }^{\#} p<0.05$, relative to OAS \\
group
\end{tabular}

Table 4: AC and PDE activities $(n=10)$

\begin{tabular}{|c|c|c|c|c|}
\hline \multirow{2}{*}{ Group } & \multicolumn{2}{|c|}{ AC ( $\mu \mathrm{g} / \mathrm{mg}$ protein) } & \multicolumn{2}{|c|}{ PDE (ng/mg protein) } \\
\hline & Testis & Epididymis & Testis & Epididymis \\
\hline Control & $\begin{array}{c}5.95 \pm \\
0.76\end{array}$ & $3.23 \pm 0.50$ & $\begin{array}{c}96.42 \\
\pm \\
10.36\end{array}$ & $\begin{array}{c}80.25 \pm \\
9.59\end{array}$ \\
\hline OAS & $\begin{array}{c}2.27 \pm \\
0.36^{\star}\end{array}$ & $1.39 \pm 0.23^{*}$ & $\begin{array}{c}243.66 \\
\pm \\
36.76\end{array}$ & $\begin{array}{c}190.33 \pm \\
17.75^{*}\end{array}$ \\
\hline TFCC & $\begin{array}{l}4.41 \pm \\
0.68^{* \#}\end{array}$ & $\begin{array}{l}2.66 \pm \\
0.32^{* \#}\end{array}$ & $\begin{array}{c}137.62 \\
\pm \\
20.33^{* \#}\end{array}$ & $\begin{array}{c}114.56 \pm \\
16.85^{*}\end{array}$ \\
\hline$F$ & 87.61 & 71.22 & 92.48 & 37.75 \\
\hline $\begin{array}{l}P- \\
\text { value }\end{array}$ & $\begin{array}{c}< \\
0.001\end{array}$ & $<0.001$ & 0.003 & $<0.001$ \\
\hline
\end{tabular}

$P<0.05$, relative to control group; ${ }^{\#} p<0.05$ when compared to OAS group

\section{Serum levels of reproductive hormones in mice}

As shown in Table 5, there were markedly higher serum levels of FSH and LH in OAS group than in control, but treatment with TFCC significantly reduced the levels of these hormones $(p<0.05)$. Ornidazole-induced oligoasthenospermia markedly reduced testosterone level, relative to control group $(p<0.05)$. However, treatment with TFCC did not significantly reverse the decrease in testosterone level $(p>0.05)$.

\section{DISCUSSION}

Oligoasthenospermia is a common cause of male infertility, and its incidence is on the increase [6]. The present strategies used for the 
management of male infertility only serve as mere palliatives. In TCM, it is believed that male infertility is due to kidney gas deficiency, low spermatogenic function and reduced spermatozoa vitality [7].

Table 5: Levels of reproductive hormones in mice $(\mathrm{n}=$ 10)

\begin{tabular}{|c|c|c|c|c|}
\hline Group & $\mathbf{n}$ & $\begin{array}{l}\text { FSH } \\
(\mu \mathrm{g} / \mathrm{L})\end{array}$ & LH (IU/L) & $\begin{array}{c}\text { Testosterone } \\
\text { (ng/L) }\end{array}$ \\
\hline Control & 10 & $\begin{array}{c}6.52 \pm \\
1.41\end{array}$ & $\begin{array}{c}14.89 \pm \\
1.73\end{array}$ & $1.72 \pm 0.50$ \\
\hline OAS & 10 & $\begin{array}{c}11.89 \pm \\
1.58^{*}\end{array}$ & $\begin{array}{c}16.73 \pm \\
1.99^{*}\end{array}$ & $1.07 \pm 0.25^{\star}$ \\
\hline TFCC & 10 & $\begin{array}{l}6.83 \pm \\
1.05^{* \#}\end{array}$ & $\begin{array}{c}13.09 \pm \\
1.36^{\star \#}\end{array}$ & $1.13 \pm 0.13^{*}$ \\
\hline$f$ & & 48.81 & 11.29 & 11.75 \\
\hline$P$-value & & $<0.001$ & $<0.001$ & $<0.001$ \\
\hline
\end{tabular}

Extracts of Cuscuta chinensis have been shown to improve semen quality, liver and kidney functions, and facilitate urine formation. The plant is renowned for its high content of total flavonoids [8].

In the present study, ornidazole-induced oligoasthenospermia significantly reduced sperm quality in mice. However, after treatment with TFCC, the quality of sperm was significantly improved, relative to the OAS group. These results suggest that TFCC may effectively increase sperm density and number, and prevent sperm damage in ornidazole-induced oligoasthenospermia.

Oxidative stress is the main factor responsible for reduced sperm density and number. Reactive oxygen species (ROS) are products of normal aerobic metabolism. They include hydroxyl radical $\left(\mathrm{OH}^{\circ}\right)$, hydrogen peroxide $\left(\mathrm{H}_{2} \mathrm{O}_{2}\right)$, and superoxide anion $\left(\mathrm{O}^{2-}\right)$. Under physiological conditions, the production and removal of ROS are in a state of dynamic equilibrium. However, in oligoasthenospermia, like in most other diseases, the production of ROS exceeds the body's natural ability to remove them, thereby resulting in the over-utilization of antioxidant enzymes and sperm damage due to oxidative attack on sperm membrane $[9,10]$.

The antioxidant enzymes in seminal fluid help maintain the dynamic equilibrium between ROS production and removal. Superoxide dismutase (SOD) is an important scavenger of ROS and plays a central role in scavenging free radicals and lipid peroxides. Malondialdehyde (MDA) is the product of the interaction between ROS and polyunsaturated fatty acids on surface of sperm membrane, and it indirectly reflects the level of free radicals and degree of damage due to lipid peroxidation in cell membranes $[11,12]$.

In the present study, the levels of ROS and MDA in the testis and epididymis were significantly increased in the OAS group, relative to control group. However, treatment with TFCC significantly reduced their levels in these tissues. In contrast, the activities of SOD and GPx were significantly reduced in reproductive tissues of mice in OAS group, relative to the control group, but were significantly increased after treatment with TFCC. Thus, TFCC alleviates the stress response in testis and epididymis in ornidazoleinduced oligoasthenospermia.

Oxidative stress not only damages sperm, it also incapacitates it by disrupting pathways of signal transduction in sperm. Adenylate cyclase (AC) is an ubiquitous effector molecule widely employed in signal transduction pathways. Cyclic adenosine monophosphate (cAMP) produced in the reaction catalyzed by $A C$ is an important second messenger in sperm, and it plays a key role in sperm capacitation and acrosome reaction [13].

Phosphodiesterase (PDE) catalyzes the hydrolysis of CAMP, thereby reducing its concentration and affecting downstream signaling pathways, which promote sperm function. The results of this study showed that ornidazole-induced oligoasthenospermia significantly reduced the activity of $A C$ in the mice. However, after treatment with TFCC, AC activity was significantly increased, relative to the OAS group. In contrast, the activity of PDE was significantly higher in reproductive tissues of mice in OAS group than in control group, but was significantly reduced after treatment with TFCC. These results are in agreement with those previously reported [14]. It is likely that TFCC promotes sperm capacitation and acrosome reaction via activation of $A C$ activity in the testis and epididymis.

Follicle-stimulating hormone (FSH) promotes follicular development and maturation, and acts mainly on spermatogenic epithelial cells. An elevated serum FSH causes damage to spermatogenic epithelial cells [15]. Luteinizing hormone (LH) acts primarily on Leydig cells, promotes their proliferation and stimulates the synthesis and secretion of testosterone by these cells in preparation for spermatogenesis.

Studies have shown that there is a close relationship between serum levels of reproductive hormones and sperm quality. 
Damage to sperm epithelium and spermatogenic dysfunction with the involvement of interstitial cells lead to increases in serum levels of $\mathrm{FSH}$ and $\mathrm{LH}$ [16]. In this study, serum levels of $\mathrm{FSH}$ and LH were markedly increased in OAS group, relative to control mice, but treatment with TFCC significantly reduced the elevated levels of these hormones. Ornidazole-induced oligoasthenospermia significantly reduced the level of testosterone, when compared with control group. However, treatment with TFCC did not significantly increase the reduced testosterone level. These results suggest that TFCC may regulate the levels of reproductive hormones and improve sperm quality in mice with oligoasthenospermia.

\section{CONCLUSION}

The results obtained in this study suggest that TFCC effectively improves sperm quality and reduces oxidative damage in testis and epididymis of mice afflicted with oligoasthenospermia. The underlying mechanism involves the regulation of serum levels of reproductive hormones. Thus, TFCC has good potential for clinical application in the management of oligoasthenospermia.

\section{DECLARATIONS}

\section{Conflict of interest}

No conflict of interest is associated with this work.

\section{Contribution of authors}

This work was done by the author named in this article and the authors accept all liability resulting from claims which relate to this article and its contents. The study was conceived and designed by Bin Chen; Hongliang Cui, Panpan Dong and Bin Chen collected and analysed the data. Hongliang Cui wrote the manuscript. All authors have read and approved the text prior to publication.

\section{Open Access}

This is an Open Access article that uses a funding model which does not charge readers or their institutions for access and distributed under the terms of the Creative Commons Attribution License (http://creativecommons.org/licenses/by/ 4.0) and the Budapest Open Access Initiative (http://www.budapestopenaccessinitiative.org/rea d), which permit unrestricted use, distribution, and reproduction in any medium, provided the original work is properly credited.

\section{REFERENCES}

1. Arabi M. Nicotinic infertility: assessing DNA and plasma membrane integrity of human spermatozoa. Andrologia 2015; 36(5): 305-310.

2. Wang $Q$, Zhou WB, Hong ZM, Zeng $Y L$, Deng L, Chen $D L$. Experience of spleen and kidney related treatment for oligoasthenospermia. Chin J Basic Med 2015; 3(3): 365-367.

3. Dinesh Yadav DM, Muralidhar MN, Prasad SMVK, Rajender Rao K. Pre-pubertal diet restriction reduces reactive oxygen species and restores fertility in male WNIN/Obese rat. Andrologia 2017; 50(1): 12849.

4. Sun JJ, Wu XJ, Bao J, Ouyang G, Zhang PL, Xv QY, Ma $B$, Zhang $Q$. Therapeutic effect and mechanism of total flavonoids from Cuscuta chinensis on oligoasthenospermia induced by hydrocortisone in rats. West China J Pharm Sci 2016; 31(1): 14-17.

5. World Health Organization. Principles of laboratory animal care. WHO Chron 1985; 39: 51-56.

6. Chen ZJ, Shi $Y$, Sun $Y$, Zhang $B$, Liang $X$, Cao $Y$, Yang $J$, Liu J, Wei $D$, Weng $N$, et al. Fresh versus frozen embryos for infertility in polycystic ovary syndrome. $N$ Engl J Med 2016; 375(6): 523

7. Zhang ZJ, Chen XJ, Jia YS, Duan PC, Zhang XJ. Advances in clinical treatment of oligospermia and asthenospermia with Traditional Chinese Medicine. Chin $J$ Human Sex 2015; 9(9): 71-74.

8. Wang XM, Xi XT, LiU HY, Xie B. Effects of total flavonoids of Cuscuta chinensis on apoptosis and apoptosis-related proteins of vascular smooth muscle cells. Chin J Gerontol 2015; 35(20): 5742-5744.

9. Li YJ, Han Z, Ge L Zhou CJ, Zhao YF, Wang DH, Ren J1, Niu XX, Liang CG. C-phycocyanin protects against low fertility by inhibiting reactive oxygen species in aging mice. Oncotarget 2016; 7(14): 17393-17409.

10. Bin B, Lu HW, Wang J, Wang DS, XU JX, Qin ZB, Liang JS, Pang QH, Cui JZ. Antioxidant effect of Qiangjing decoction on ornidazole-induced oligoasthenospermia in rats. Chin J Basic Med 2016; 4(4): 484-487.

11. Gen $Q$, Ouyang B, Guo J, Wang $F$, Han $Q$, Zhao Y, Li Z, Yu GJ, Gao QH, Zhang JW. Protective effect of Jiawei tianxiong powder on oxidative damage of epididymis in oligoasthenospermia model rats. Chin J Basic Med 2016; 1(1): 122-124.

12. Ni K, Steger $K$, Yang $H$, Wang $H$, Hu K, Zhang $T$, Chen B. A comprehensive investigation of sperm DNA damage and oxidative stress injury in infertile patients with subclinical, normozoospermic, and astheno/oligozoospermic clinical varicocoele. Andrology 2016; 4(5): 816-824.

13. Bin B, Lu HW, Wang J, Wang DS, Xu JX, Qin ZB, Liang JS, Pang QH, Cui JZ. Effect of Qiangjing decoction on gene expression of adenylate cyclase and 
phosphodiesterase in sperm of oligoasthenospermia rats. Chin J Basic Med 2015; 5(5): 595-597.

14. Kuang JG, Zhang SJ, Ren T, Liu P, Liu L, Liu YG, Lei ZP, Shi ML. Assessment of sperm quality and testicular tissue oxidative stress damage in oligasthenospermia rats model after reception of Jianpi yishen recipe. $J$ Hainan Med University 2016; 22(18): 2082-2085.
15. Bassey IE, Essien OE, Gali RM, Isong IKP, Udoh $A E$, Isong $A E$, Akpan $U$. The effect of smoking on fertility hormones in male adult smokers in South-South Nigeria. Br J Med Med Res 2015; 9: 1-6.

16. Deng ZB. The value of serum testosterone/luteinizing hormone, follicle stimulating hormone and luteinizing hormone in the diagnosis of testicular spermatogenesis. Int J Lab Med 2016; 37(11): 1508-1509. 